\title{
Effects of genotype and housing system on some bone biomechanical characteristics in broiler chickens
}

\author{
Bayram SÜZER ${ }^{1 a}$, Kenan TÜFEKÇí ${ }^{2 b}$, Illker ARICAN ${ }^{1 c}$, Metin PETEK $^{3 \mathrm{~d}}$, \\ Ibrahima Mahamane ABDOURHAMANE ${ }^{3 \mathrm{e}}$, Melahat ÖZBEK ${ }^{3 \mathrm{f}}$, Hüseyin YILDIZ $^{1 \mathrm{~g} \bowtie}$
}

\begin{abstract}
${ }^{1}$ Bursa Uludağ University, Faculty of Veterinary Medicine, Department of Anatomy; ${ }^{2}$ Bursa Uludağ University, Faculty of Engineering, Department of Mechanical Engineering, and Architecture; ${ }^{3}$ Bursa Uludağ University, Faculty of Veterinary Medicine, Department of Zootechnics, Bursa, Turkey.

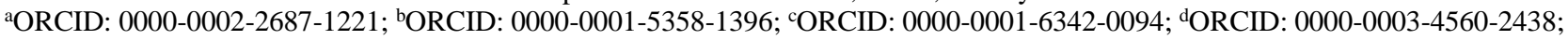
eORCID: 0000-0001-8789-3101; ${ }^{\mathrm{f} O R C I D: ~ 0000-0002-5491-1788 ; ~}{ }^{\mathrm{g} O R C I D: 0000-0002-9076-0112 .}$
\end{abstract}

${ }^{凶}$ Corresponding author: yildiz@uludag.edu.tr

Received date: 03.07.2018- Accepted date: 21.04 .2019

\begin{abstract}
The aim of this study was to determine the effects of two genotypes (slow-growing and fast-growing) and three housing systems (deep litter, plastic slat and free-range) on some bone biomechanical properties of broiler chickens and to evaluate the interaction between genotype and housing systems. Broilers from two genotypes were reared at three different housing conditions. Fifteen bones were randomly selected from each housing system in both slow-growing and fast-growing groups, and the experiment was performed on 90 bones in total. To determine bone characteristic and biomechanical traits of tibiotarsi, bones collected from right leg and then weighed, cortical area measurements and three-point bending tests were applied. Both live body weight and carcass weight were significantly affected by genotype and housing systems. There was no interaction between genotype and housing system in terms of bone weight, cortical area, breaking strength, bending strength, and deflection. Also, housing systems had no statistical effect on these parameters. Fast-growing broilers were significantly had heavier tibiotarsi, larger cortical area and higher breaking strength than slow-growing broilers, while bending strength was significantly lower in fast-growing broilers. Deflection was not affected by genotype or by housing system. In conclusion, bone geometry and biomechanical properties were not affected by housing systems but by genotype. Fast-growing broilers had better bone morphology and stronger bones than slow-growing genotype. Therefore, fast-growing genotype can provide positive effects on bone growth and mechanical properties in broilers.

Keywords: Biomechanics, broiler, genotype, housing, tibiotarsus.
\end{abstract}

\section{Etlik piliçlerde genotip ve barınma sisteminin bazı kemik biyomekanik özellikleri üzerine etkileri}

Özet: Bu çalışmanın amacı, iki genotip (yavaş ve hızlı gelişen) ve üç barınak sisteminin (derin altlık, plastik ızgara ve serbest dolaşım) etlik piliçlerin bazı kemik biyomekanik özellikleri üzerindeki etkilerini belirlemek ve genotip ve barınak sistemleri arasında etkileşimi değerlendirmektir. İki farklı genotipe ait etlik piliçler üç farklı barınma sisteminde yetiştirildi. Hem yavaş gelişen hem de hızlı gelişen genotipe sahip etlik piliçlerde her bir konut sisteminden 15 kemik olacak şekilde rastgele seçildi ve deney toplam 90 kemik üzerinde gerçekleştirildi. Kemik özellikleri ve biyomekanik karakterlerinin belirlenmesi için sağ bacaklardan elde edilen tibiotarsuslar kullanıldı ve sonra bu kemikler tartılarak, kortikal alan ve üç nokta eğme testine tabi tutuldu. Hem canlı ağırlık hem de karkas ağırlığı, genotip ve konut sistemlerinden istatistiksel olarak etkilenmiştir. Kemik ağırlığı, kortikal alan, kırılma mukavemeti, eğilme gerilimi ve bükülme açısından genotip ve barınma sistemleri arasında herhangi bir etkileşim bulunamadı. Ayrıca, barınma sisteminin istatistiksel olarak bu parametreler üzerinde herhangi bir etkisinin olmadığı gözlendi. Yavaş gelişen etlik piliçlerin daha düşük eğilme gerilimi sahipken, hızlı gelişenlerin belirgin şekilde daha yüksek kemik ağırlığı, kemik kortikal alanı ve kırılma mukavemeti değerlerine sahip olduğu gözlendi. Ne genotipin ne de barınma sisteminin bükülme üzerine herhangi bir etkisi bulunamadı. Sonuç olarak, kemik geometrisi ve biyomekanik özellikler, barınma sistemlerinden değil, genotipten etkilenmiştir. Hızlı gelişen etlik piliçler, yavaş gelişenlerden daha iyi kemik morfolojisine ve daha güçlü kemiklere sahip olduğu gözlendi. Bu nedenle hızlı gelişen genotip, etlik piliçlerde kemik gelişimi ve mekanik özellikleri üzerinde olumlu etkiler sağlayabilir.

Anahtar sözcükler: Barınma, biyomekanik, etlik piliç, genotip, tibiotarsus.

\section{Introduction}

The demands of customers for different poultry products have been shaped by different commercial breeding systems (53). In recent years, organic and freerange (FR) products have become more available to customers $(13,18)$. However, environmental conditions, 
human population density, and land availability limit the use of organic or FR farming systems (20). Confined systems such as caged rearing are still used in broiler production (9).

Although intensive genetic selection for fastgrowing (FG) broilers has shortened the growing period considerably, some undesirable results, such as excessive feed intake and carcass fatness, have also occurred (41). Several factors for example nutrition, sex, strain, housing and stocking density affect growth performance and carcass characteristics of broiler chickens (3). Some studies have also reported that genotype affected body weight, body weight gain, feed intake and feed conversion ratio in broiler chickens $(48,52)$.

Most natural and organic poultry industries in the United States use an FG broiler genotype, which is the same as in classical production systems (20). Although growth performance of FG chickens is more efficient than slow-growing (SG) genotypes, some researchers suggested that SG chickens adapt to native systems more easily $(6,25)$. In general, broiler chickens have been bred for growing rapidly and they reach market weight by the age of 42 to 45 days. However, there is a rising trend to produce heavier chickens in the broiler industry $(24,60)$. Therefore, the poultry industry is based on intense production systems using FG genetic strains with high yield of breast muscle (34). For several decades, modern high-yield meat chicken has undergone very successful genetic selection to reduce the time and the feed required for reach the target body weight. However, it has been known for several years that rapid increase in body weight cause several undesirable effects on respiratory, reproductive and skeletal systems of broilers (12, 17, 24, $26,31,35)$. Such applications in the poultry industry pose a risk to animal welfare and increase the stress to the animals, potentially causing lameness, foot pad dermatitis and hock burn lesions, ascites and metabolic disorders (11).

Gait problems in broiler chickens has become a major problem, not only because they cause losses in the market and slaughterhouse, but also to affect the broilers' welfare negatively (1). However, for producing low cost meat, optimizing the production for high yield characteristics of those chickens has resulted with poor walking or locomotor ability, reduced viability and welfare (4). Obviously, skeletal leg health is important in terms of both economic considerations and the welfare of broiler chickens (31).

Some researchers reported that leg health and bone strength are poorer in modern wide-breast broilers than in unselected broilers $(16,22,26,35,46)$. Kestin et al. (21) found significant differences in certain parameters of leg health in broiler chickens. In contrast, Yalcin et al. (57) did not observed any differences in bone breaking strength in the two different commercial broiler genotypes.

Housing systems also affect bone growth and breaking strength in poultry species. Conventional confined systems cause stress that may result in physiological and behavioral disorders (27, 38). FR systems may decrease stress and increase comfort and welfare (50). Tolon and Yalcin (49) reported that caged systems led to a decrease in humerus weight but did not affect tibia weight in broilers. Merkley and Wabeck (29) also observed that caged broilers had lower bone breaking strength than broilers grown in a conventional litter.

The objective of this study was to evaluate the effects of different housing systems on the biomechanical properties of tibiotarsus in broiler chickens with FG and SG genotypes.

\section{Materials and Methods}

This study was carried out at the Poultry Breeding Unit of Bursa Uludağ University Veterinary Faculty Animal Health and the Animal Production Research Center. The study was performed with the permission of the Bursa Uludağ University Animal Experimentation Local Ethics Committee (No: 01.09.2015-91).

Animals and groups: The study was designed to examine the effect of two broiler genotypes (SG and FG genotypes) with three housing systems [deep litter (DL), plastic slat (PS) and free-range (FR)] on the tibiotarsus of broiler chickens. One-day-old, Hubbard JA-57 SG and Ross 308 FG broiler chicks were purchased from a local commercial poultry farm. In the study, $2 \times 3=6$ main groups were formed, and each main group was composed of five replicates. Each replicated group had 10 male chicks. Therefore, each main group included 50 chickens. In total, 300 chickens (150 SG genotype and 150 FG genotype chickens) were used. Fifteen bones were randomly selected from each housing system in both SG and FG groups, and the experiment was performed on 90 bones in total. All broiler chickens used in the study were raised for 56 days and then they were slaughtered at $4403.30 \pm 77 \mathrm{~g}$ and $2385.66 \pm 77 \mathrm{~g}$ body weight for fastgrowing and slow-growing broilers, respectively.

Housing systems and season: The study was carried out in May to June. Range area was covered by mesh canopy and no feed was provided in the range area. Deep litter was used as the confined system and shelter for the FR system. Plastic slat floor was used for the PS system. The DL system consisted of broilers reared indoors on rice husk litter, which was not changed throughout the rearing period, and the density of litter was $7 \mathrm{~kg} / \mathrm{m}^{2}$ and the depth of litter was $5 \mathrm{~cm}$. Mean stocking density within the groups was 10 birds per $1 \mathrm{~m}^{2}$ indoor and $5 \mathrm{~m}^{2}$ outdoor for just the birds in free range group. The pasture consisted of alfalfa (Medicago sativa) 36\%, pursley (Portulaca 
oleracea) 4\%, groundsel (Senecio vulgaris) 28\%, cocklebur (Xanthium Spinosum) 32\%. The PS system consisted of broilers reared indoors on plastic slat floors. The plastic slats measured $1.2 \times 0.5 \mathrm{~m}$ (length $\times$ width) and were raised above the concrete floor by 0.5 meters to accumulate manure below.

Feed and lighting schedule: Hanging tube feeders (each $30 \mathrm{~cm}$ in diameter with $10-15 \mathrm{~kg}$ capacity) and bell drinkers were provided for the birds in all groups. All birds in all groups received a commercial multiphase diet (i.e., starter feed from days 0 to days 15 , grower feed I from days 15 to days 30, grower feed II from days 30 to days 40 , and finisher from days 40 to until the end of the experiment) (Table 1), which was produced and supplied by a commercial feed company in Turkey. Water and feed were provided ad libitum.

The birds were allowed access to range area at the beginning of 21 days of age in free range groups. During the experimental period, birds in free range groups had continuous access to outdoor range during daylight hours without any restrictions. The daily photoperiod consisted of $2 \mathrm{~h}$ of light and $2 \mathrm{~h}$ of darkness during the night and continuous day-light. During the day, daylight was used a light source and tungsten lights were used during the dark period. The lighting intensity was arranged as $5.01 \mathrm{x} \mathrm{m}^{2}$ for all groups.

Bone weight, cortical area and biomechanical tests: Right leg tibiotarsi were collected, dissected of surrounding soft tissues, weighed and wrapped with Phosphate-buffered Saline (PBS) soaked gauze then frozen at $-20{ }^{\circ} \mathrm{C}$ until mechanical tests and cortical area analysis were conducted (47). The tibiotarsi were weighed with a Precisa XB4200C digital scale (Precisa Instruments Ltd., Switzerland). The bone cross section was considered an approximate hollow ellipsoid of varying thickness (Figure 1). To simplify the calculation of section properties as done in a previous study (32), the thickness value used in the following stress equation was calculated by taking the average of the measured thickness values of the four quadrants from lateral $\left(\mathrm{t}_{1}\right)$, anterior $\left(\mathrm{t}_{2}\right)$, medial $\left(t_{3}\right)$, posterior $\left(t_{4}\right)$ of the tibia.

Table 1. Composition and nutrient levels of the experimental diet.

Tablo 1. Yem kompozisyonu ve besin değerleri.

\begin{tabular}{|c|c|c|c|c|c|}
\hline Ingredients & Unit & $\begin{array}{l}\text { Starter } \\
(0-10 \text { d })\end{array}$ & $\begin{array}{l}\text { Grower I } \\
(11-23 \text { d) }\end{array}$ & $\begin{array}{c}\text { Grower II } \\
(24-36 \text { d) }\end{array}$ & $\begin{array}{l}\text { Finisher } \\
\text { (37-56 d) }\end{array}$ \\
\hline Crude Protein & $\%$ & 23.00 & 21.00 & 19.95 & 19.00 \\
\hline Crude Fiber & $\%$ & 3.80 & 3.30 & 3.30 & 4.27 \\
\hline Crude Fat & $\%$ & 5.46 & 6.40 & 6.50 & 8.01 \\
\hline Crude Ash & $\%$ & 5.05 & 5.05 & 5.05 & 5.05 \\
\hline Calcium & $\%$ & 1.05 & 0.90 & 0.85 & 0.85 \\
\hline Phosphorous & $\%$ & 0.64 & 0.64 & 0.60 & 0.60 \\
\hline Sodium & $\%$ & 0.16 & 0.17 & 0.16 & 0.16 \\
\hline Lysine & $\%$ & 1.43 & 1.30 & 1.14 & 1.09 \\
\hline Methionine & $\%$ & 0.51 & 0.54 & 0.48 & 0.41 \\
\hline E672 Vitamin A & IU & 11000 & 10000 & 10000 & 10000 \\
\hline E671 Vitamin D3 & IU & 5000 & 4000 & 4000 & 4000 \\
\hline 51774 - Nicarbazin & $\mathrm{mg}$ & 125 & 125 & - & - \\
\hline E1 Iron (Ferrous sulphate 30\%) & $\mathrm{mg}$ & 50 & 50 & 50 & 50 \\
\hline E4 Copper (Cupric sulphate 25\%) & $\mathrm{mg}$ & 16 & 16 & 16 & 16 \\
\hline E6 Zinc (zinc oxide) & $\mathrm{mg}$ & 100 & 100 & 100 & 100 \\
\hline Manganese (Manganous oxide 60\%) & $\mathrm{mg}$ & 100 & 100 & 100 & 100 \\
\hline E2 Iodine (Calcium iodate $6.2 \%$ ) & $\mathrm{mg}$ & 2 & 2 & 2 & 2 \\
\hline E8 Selenium (Sodium selenite $4.5 \%$ ) & $\mathrm{mg}$ & 0.20 & 0.20 & 0.20 & 0.20 \\
\hline EC 3.1.26 - 6 Phytase & FTU & 1000 & 1000 & 1000 & 1000 \\
\hline EC 3.2.2.8 - Endo-1.4 beta xylanase & $\mathrm{u} / \mathrm{g}$ & - & 1500 & 1500 & - \\
\hline EC 3.2.1.1 - Alfa Amylase & $\mathrm{u} / \mathrm{g}$ & - & 2000 & 2000 & - \\
\hline EC 3.4.21.62 - Subtilisin (Protease) & $\mathrm{u} / \mathrm{g}$ & - & 20000 & 20000 & - \\
\hline E558 - Bentonite/Montmorillonite & $\mathrm{mg}$ & - & 700 & 700 & - \\
\hline E776 - Salinomycin Sodium & $\mathrm{mg}$ & - & - & 60 & - \\
\hline
\end{tabular}

Diet and analysis nutrient composition were obtained from a commercial feed company. 


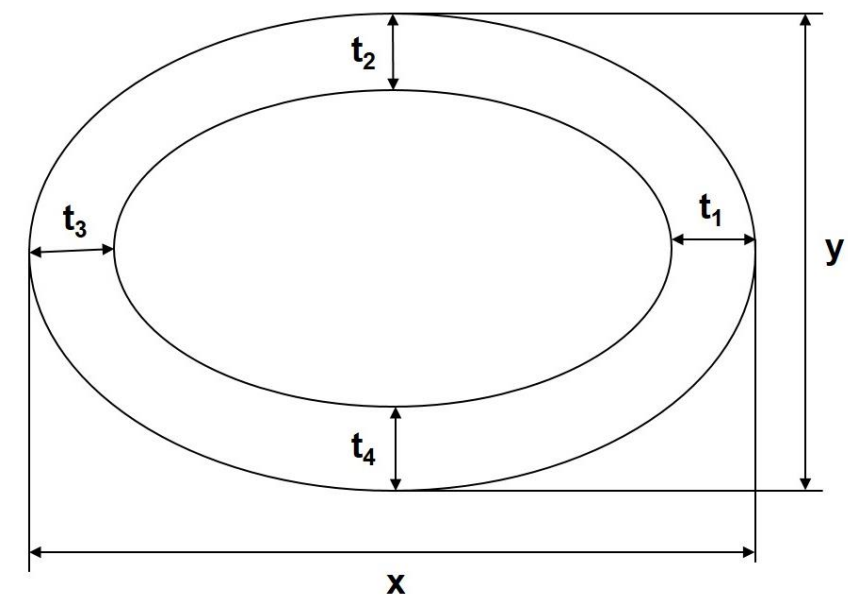

Figure 1. Geometry and dimensions of bone cross-section. $\mathrm{t}_{1}=$ lateral, $\mathrm{t}_{2}=$ anterior, $\mathrm{t}_{3}=$ medial, $\mathrm{t}_{4}=$ posterior. Şekil 1. Kemik kesitinin geometrisi ve ölçümler. $\mathrm{t}_{1}=$ lateral, $\mathrm{t}_{2}=$ anterior, $\mathrm{t}_{3}=$ medial, $\mathrm{t}_{4}=$ posterior.

Figure 2. Three-point bending test apparatus. Şekil 2. Üç nokta eğme testi aparatı.

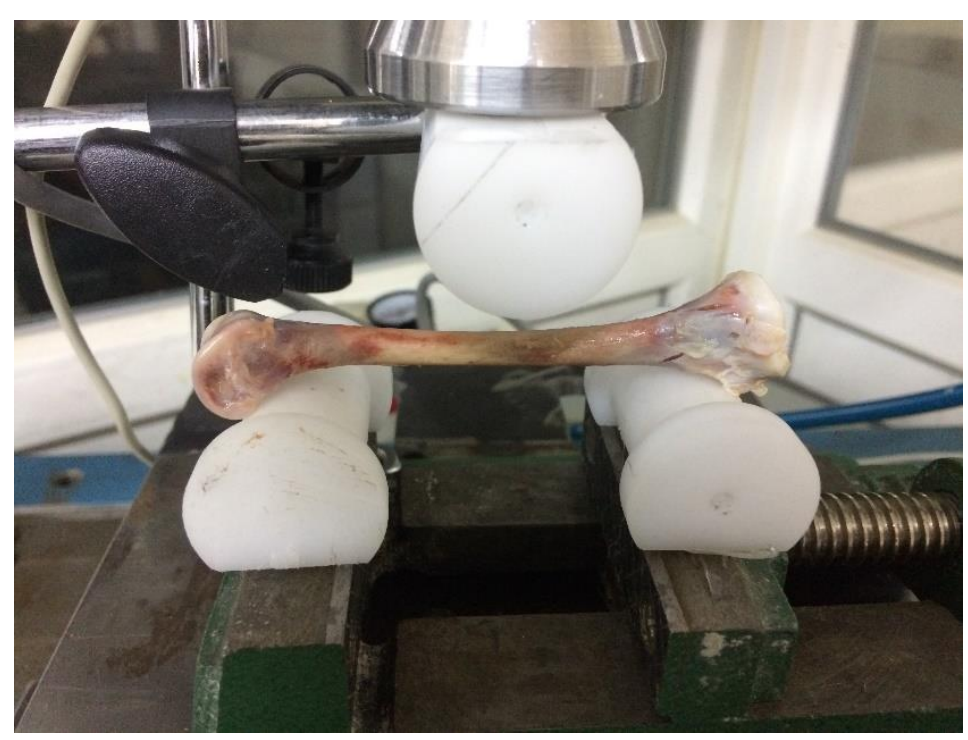

Three-point bending tests were performed with a custom-made testing machine, which was designed for low strength materials (51). A load-cell (50 N, Tedea Huntleigh Malvern, USA) and a Linear Variable Differential Transformer (LVDT) (10-mm stroke, Novotechnik Tr10, Germany) were used to measure force and corresponding deflection during tests, respectively. Force and deflection measurements were recorded by using an oscilloscope (Nicholet-Oddysey XE, USA) at the rate of 100 data/sec. The experimental results can be affected by displacement rate; therefore, all tests were performed at a constant displacement rate of $10 \mathrm{~mm} / \mathrm{min}$, as suggested by a previous study (2). The span of the support roller was set to $70 \mathrm{~mm}$, and the force was applied at the middle of the span (Figure 2).

Bone breaking strength was attained by reading the highest value of the load-deflection curve. By using recorded force data and geometrical properties of the damaged sample, bending strength $\left(\sigma_{\max }\right)$ was calculated as follows:

$$
\boldsymbol{\sigma}_{\text {max }}=\frac{8 F_{\max } L y}{\pi\left[x y^{3}-(x-2 t)(y-2 t)^{3}\right]}
$$

Where $F_{\max }$ is the maximum load recorded from the load-deflection curve, $L$ is span of the bending test fixture, $t$ is average thickness value, and $x$ and $y$ are the outer diameters of the ellipse.

Bone breaking strength refers to the maximum load or force that a bone structure can withstand before fracture. In addition, maximum load is synonymous with whole-bone strength. Bending strength or ultimate stress is the highest load per unit area that bone-tissue can withstand before fracture. Deflection is the displacement of bone structure from the start of the bending process until fracture. Cortical area is important to define the total amount of bone at the diaphysis and to report. The engineering theory for compression or stress loading states that cortical area is the most appropriate morphological parameter (19).

Statistical analysis: Statistical analyses were performed using IBM $^{\circledR}$ SPSS $^{\circledR}$ (SPSS, Version 23.0; Chicago, IL, USA). To determine the main effects and interactions between groups, experimental groups considered as $2 \times 3$ factorial design and Two-way ANOVA was used for statistical evaluation. Linear 
regression analysis was used to identify the regression equations between body weight and bone properties. Differences were considered statistically significant at the level of $\mathrm{P}=0.05$. Differences between groups were assessed by the Duncan multiple range test when statistically significant differences were found. Furtherly, One-way ANOVA was performed for the differences between interactive group data (45).

\section{Results}

The effects of genotype and housing systems on bone parameters (bone weight, cortical area, breaking strength, bending strength and deflection) are shown in Table 2 .

The regression equations and coefficient of determination $\left(\mathrm{R}^{2}\right)$ between live body weight and bone properties are presented in the Table 3 .

Table 2. Effects of genotype and housing system on live body weight, carcass weight, bone weight, cortical area, bone breaking strength, bending strength and deflection.

Tablo 2. Genotip ve barınma sisteminin canlı ağırlık, karkas ağırlığı, kemik ağırlığı, kortikal alan, kemik kırılma mukavemeti, eğilme gerilimi ve bükülme üzerine etkileri.

\begin{tabular}{|c|c|c|c|c|c|c|c|}
\hline & $\begin{array}{l}\text { Live body } \\
\text { weight (g) }\end{array}$ & $\begin{array}{c}\text { Carcass weight } \\
\text { (g) }\end{array}$ & $\begin{array}{c}\text { Bone weight } \\
\text { (g) }\end{array}$ & $\begin{array}{l}\text { Cortical area } \\
\qquad\left(\mathbf{m m}^{2}\right)\end{array}$ & $\begin{array}{l}\text { Bone breaking } \\
\text { strength }(\mathrm{N})\end{array}$ & $\begin{array}{l}\text { Bending } \\
\text { strength } \\
\left(\mathbf{N} / \mathbf{m m}^{2}\right)\end{array}$ & $\begin{array}{l}\text { Deflection } \\
\quad(\mathbf{m m})\end{array}$ \\
\hline \multicolumn{8}{|c|}{ Genotype } \\
\hline FG & $4403.30 \pm 77$ & $3588.815 \pm 62.688$ & $31.169 \pm 0.683$ & $68.820 \pm 2.103$ & $438.009 \pm 19.576$ & $104.253 \pm 6.961$ & $2.877 \pm 0.090$ \\
\hline SG & $2385.66 \pm 77$ & $1825.533 \pm 61.559$ & $19.597 \pm 0.679$ & $41.637 \pm 2.094$ & $293.699 \pm 19.621$ & $154.359 \pm 6.974$ & $3.027 \pm 0.087$ \\
\hline \multicolumn{8}{|c|}{ Housing system } \\
\hline DL & $3233.75 \pm 95^{b}$ & $2572.122 \pm 77.459^{b}$ & $24.707 \pm 0.836$ & $51.700 \pm 2.604$ & $346.203 \pm 24.037$ & $132.357 \pm 8.532$ & $2.770 \pm 0.112$ \\
\hline PS & $3306.50 \pm 93^{b}$ & $2878.700 \pm 75.393^{\mathrm{a}}$ & $25.340 \pm 0.840$ & $54.493 \pm 2.576$ & $361.113 \pm 24.018$ & $128.420 \pm 8.544$ & $2.986 \pm 0.107$ \\
\hline FR & $3643.20 \pm 94^{\mathrm{a}}$ & $2670.700 \pm 75.393^{\mathrm{ab}}$ & $26.103 \pm 0.839$ & $59.492 \pm 2.580$ & $390.245 \pm 24.022$ & $127.141 \pm 8.541$ & $3.100 \pm 0.110$ \\
\hline \multicolumn{8}{|c|}{ Genotype x Housing system } \\
\hline $\mathrm{FG} \times \mathrm{DL}$ & $4277.50 \pm 133^{b}$ & $3534.000 \pm 106.62^{\mathrm{b}}$ & $30.032 \pm 1.183$ & $63.614 \pm 3.643$ & $421.504 \pm 33.923$ & $108.890 \pm 12.079$ & $2.736 \pm 0.148$ \\
\hline $\mathrm{FG} \times \mathrm{PS}$ & $4115.50 \pm 132^{\mathrm{b}}$ & $3324.444 \pm 112.39^{\mathrm{b}}$ & $31.194 \pm 1.170$ & $66.984 \pm 3.621$ & $434.910 \pm 33.897$ & $111.184 \pm 12.089$ & $2.902 \pm 0.153$ \\
\hline $\mathrm{FG} \times \mathrm{FR}$ & $4817.20 \pm 131^{\mathrm{a}}$ & $3908.000 \pm 106.62^{\mathrm{a}}$ & $32.282 \pm 1.186$ & $75.862 \pm 3.656$ & $457.612 \pm 33.946$ & $92.686 \pm 12.083$ & $2.994 \pm 0.149$ \\
\hline $\mathrm{SG} \times \mathrm{DL}$ & $2335.80 \pm 133^{\mathrm{c}}$ & $1807.400 \pm 106.62^{c}$ & $19.382 \pm 1.184$ & $39.786 \pm 3.648$ & $270.902 \pm 33.984$ & $155.824 \pm 12.072$ & $2.804 \pm 0.159$ \\
\hline $\mathrm{SG} \times \mathrm{PS}$ & $2352.00 \pm 130^{c}$ & $1819.800 \pm 106.62^{c}$ & $19.486 \pm 1.177$ & $42.002 \pm 3.635$ & $287.316 \pm 33.967$ & $145.656 \pm 12.076$ & $3.070 \pm 0.150$ \\
\hline $\mathrm{SG} \times \mathrm{FR}$ & $2469.20 \pm 132^{c}$ & $1849.400 \pm 106.62^{c}$ & $19.924 \pm 1.172$ & $43.122 \pm 3.620$ & $322.878 \pm 33.960$ & $161.596 \pm 12.084$ & $3.206 \pm 0.147$ \\
\hline \multicolumn{8}{|c|}{$\mathbf{P}$} \\
\hline Genotype & 0.001 & 0.000 & 0.000 & 0.000 & 0.000 & 0.000 & 0.250 \\
\hline $\begin{array}{l}\text { Housing } \\
\text { system }\end{array}$ & 0.008 & 0.020 & 0.507 & 0.117 & 0.432 & 0.904 & 0.118 \\
\hline $\begin{array}{l}\text { Genotype } \\
\times \text { Housing } \\
\text { system }\end{array}$ & 0.095 & 0.043 & 0.769 & 0.426 & 0.970 & 0.368 & 0.893 \\
\hline
\end{tabular}

Table 3. The regression equation and coefficient of determination between live body weight and bone properties in fast- and slowgrowing broilers.

Tablo 3. Hızlı ve yavaş gelişen etlik piliçlerde canlı ağırlık ve kemik özellikleri arasındaki regresyon formülü ve determinasyon katsayisı.

\begin{tabular}{lcccccc}
\hline \multirow{2}{*}{ Bone properties } & \multicolumn{3}{c}{ Fast-growing genotype } & \multicolumn{3}{c}{ Slow-growing genotype } \\
\cline { 2 - 7 } & $\mathbf{R}^{\mathbf{2}}$ & Regression equation & $\mathbf{P}$ & $\mathbf{R}^{\mathbf{2}}$ & Regression equation & P \\
\hline Bone weight & 0.282 & $21.906+0.002 \times \mathrm{BW}$ & 0.003 & 0.130 & $20.477+0.001 \times \mathrm{BW}$ & 0.548 \\
Cortical area & 0.168 & $115.626+0.005 \times \mathrm{BW}$ & 0.025 & 0.130 & $45.910+-0.002 \times \mathrm{BW}$ & 0.553 \\
Bone breaking strength & 0.142 & $265.121+0.040 \times \mathrm{BW}$ & 0.040 & 0.005 & $314.093+-0.008 \times \mathrm{BW}$ & 0.712 \\
Bending strength & 0.011 & $115.626+-0.003 \times \mathrm{BW}$ & 0.584 & 0.002 & $147.702+0.003 \times \mathrm{BW}$ & 0.828 \\
Deflection & 0.254 & $1.900+0.001 \times \mathrm{BW}$ & 0.005 & 0.001 & $3.059+-1.315 \times \mathrm{BW}$ & 0.924 \\
\hline
\end{tabular}

$\mathrm{R}^{2}$ : Coefficient of determination; BW: Body weight. 
Live body weight at slaughter (BW) age was significantly higher in FG broilers compare to SG broilers $(\mathrm{P}<0.05)$. BW was also significantly different among housing systems and the FR group were heavier than the DL and PS groups. But the interaction (genotype $\times$ housing system) was not significant for body weight. In terms of carcass weight, significant differences were observed in both genotype and housing systems. Accordingly, the PS group were heavier than the DL group, but the difference was not significant for FR group. There was also significant interaction (genotype $\times$ housing system) for carcass weight. Housing systems had no statistical effect on bone weight, cortical area, breaking strength, bending strength, and deflection. Furthermore, there was no interaction between genotype and housing system in terms of these parameters. In contrast, bone weight, cortical area, breaking strength and bending strength were significantly affected by genotype $(\mathrm{P}<0.05)$. According to this, FG broilers were significantly higher in bone weight, cortical area and breaking strength than SG genotypes, while bending strength was significantly lower in FG broilers ( $P$ $<0.05)$. But it was observed that deflection was not affected either by genotype or by housing system. In FG broilers, changes in body weight had significant positive effects on bone weight, cortical area, breaking strength and deflection $(\mathrm{P}<0.05)$. But, bending strength was not affected from body weight changes. Changes in body weight did not affect the bone parameters in SG broilers.

\section{Discussion and Conclusion}

It is well known that fast-growing broilers have been selected and bred for rapid early growth and reach market weight in about $42 \mathrm{~d}$. But slow-growing broilers reach market weight at 63 to 81 days of age (15). Because of their rapid development FG broilers obviously become heavier at slaughter age than slow-growing broilers. In the present study, FG broilers had higher live weight at slaughter age and carcass weight compare to SG broilers as expected.

Castellini et al. (7) suggested that organic free-range broilers had lower growth performance than broilers in conventional systems due to higher locomotor activity. In contrast, we observed FR broiler significantly higher body weight than those in other housing systems. Similar results were reported by Santos et al. (43) and Ponte et al. (36) showed significantly higher body weight in broiler chickens that had free access to pasture. Likewise, Bogosavljević-Bosković et al. (5) observed that broilers with free-range access showed better muscle gaining compared to those reared indoors only. In the present study, the increase in BW and carcass weight might be the result of several situations. First, while broiler chicks are generally reared 42 days, our broilers were raised 56 days. During this long time, FR broilers may have adapted to the environment and locomotor activity and they might have had better feed intake (50). Second, due to improving comfort and welfare of FR broilers compared to confined systems, FR broilers might increase their feed intake and ultimately body weight $(36,43)$. Third and last, FR broilers may have had access to the various forages, insects, and worms that may be available in the pasture (55).

In this study, the carcass weight of broilers in PS group was higher than in DL group. It is consistent with Enver et al. (8) who also reported that broilers reared on plastic slats has better carcass yield than the broilers raised on deep litter. PS group showed better performance as it had less contact with litter and more comfortable environment. Inconvenient and wet litter reduces overall health, welfare, performance and carcass yield in broilers reared on the deep litter $(10,33)$.

McDevitt et al. (28) reported that the FG broilers had significantly heavier tibiotarsi and more ash and organic matter per unit length of bone than SG broilers at the same age. Similarly, in the current study, FG broilers had significantly higher bone weight than SG broilers. Knowles and Broom (23) reported that the load on bone tissue stimulates bone growth and increases mineral density. It is thought that FG broilers had stronger, heavier tibiotarsi because of the higher mineral content of the bones and the heavier body mass being carried. Those findings were consistent with our study and explained the heavier tibiotarsi found in the FG broilers.

Bone growth and breaking strength may also be affected by housing systems. Tolon and Yalcin (49) reported that caging birds led to a decrease in the weight of the humerus, but caged systems did not affect the weight of the tibiotarsus. Merkley and Wabeck (29) reported lower bone breaking strengths in wings of broilers grown in cages than in broilers grown on deep litter. In addition, Vitorovic and Nikolic (54) reported that wing bones were more affected by the housing system than were leg bones. In the present study, tibiotarsus weight was not affected by the housing system. It is thought that bone development was not significantly affected by the housing system because the chickens were not kept in strictly caged so they had more free movement opportunity. These findings suggested that bone breaking strength and weight of the tibiotarsus were affected by the genotype but not by the housing system.

Yildiz et al. (58) suggested that significant differences were observed in cortical areas of humerus between caged, aviary, perchery and litter housing systems. That study stated that larger cortical area in aviary, perchery and litter was caused by greater activity of birds in these housing systems. Reiter and Bessei (40) also reported that active birds had thicker and denser cortical bone in the tibiotarsus than less active controls. As 
explained by Wolff's Law (56), activity increases the thickness and density of cortical bone and increases the diameter of the diaphysis by deposition of bone in response to stress. In the present study, there was no significant difference in terms of cortical area among housing systems, whereas FG broilers had significantly larger cortical area than SG broilers. These results suggest that heavier bones in FG broilers have larger cortical area due to their faster growth. However, similar movement possibilities of the chickens in experimental housing systems did not significantly affect the bone cortical development.

According to bone breaking strength, bone weight and cortical area results, it was clear that the tibiotarsi of FG broilers were heavier, thicker and these broilers had a higher bone breaking strength than SG broilers. Similarly, McDevitt et al. (28) also reported that the mean breaking strength of the tibiotarsus of FG broilers at 42 days was greater than that of the SG broilers. These indicate that tibiotarsi of FG broilers were more grown and more durable. However, when bending strength values were examined, it was observed that FG genotype groups had lower bending strength values than the SG genotype groups. These results suggest that the bone composition of FG broilers was poorer than that of SG broilers, because the bending strength means the highest load per unit area where the bone tissue resists before breaking (19). In addition, the results of breaking strength and bending strength indicated that FG genotype showed the best bone geometry but not the best bone composition due to fast growth. It is well known that while breaking strength indicates that the strength of whole bone depends on geometrical and material properties, bending strength of bone depends only on material properties.

The deflection value was not affected by genotype or housing systems. But when this value is evaluated by force it is obvious that FG broilers had stiffer bones than SG broilers. This situation may be explained by the stiffer bones take more force to produce a given deflection (14).

The experimental results showed that the FG genotype causes an increase approximately $30 \%$ in bone geometric and material properties and a decrease approximately $10 \%$ in mechanical material properties. Thus, bone load carrying capacity have been increased approximately $20 \%$ in total.

Several housing or rearing system effects on bone strength have been studied on laying hens. According to these studies, hens in conventional cages have the highest fracture rates and the weakest bone resistance compared to all other housing systems. In contrast, hens in cage-free or free-range systems show the best musculoskeletal health $(42,44,59)$. Although those researchers reported that cage-free or free-range hens had better bone morphological and biomechanical properties, we found that housing system did not affect bone morphology or biomechanical properties. Consistent with our study Moyle et al. (30) reported that access to pasture or to the outdoors had no effect on the tibial bone strength on fast growing broilers. It is thought that skeletal adaptation to housing systems will be shaped as the age progresses and thus the effects on the bone can be observed $(37,39)$.

In conclusion, genotype has influenced structural and biomechanical properties of the tibiotarsus in broilers. Broilers with fast-growing genotype had better bone geometrical properties and stronger bones compare to the broilers had slow-growing genotype. There was no significant effect of housing systems on bone morphology and biomechanical properties. It is thought that the impact of the housing systems on the skeletal system will occur as the age progresses like in laying hens. Therefore, further studies are needed to examine the effects of housing systems on the bone in broilers.

\section{Acknowledgement}

Materials used in this study were obtained from the animals used in the thesis titled "Effects of different housing systems and genotypes on slaughter properties, carcass characteristics and meat quality in broiler chickens."

\section{References}

1. Almeida Paz ICL, Garcia RG, Bernardi R, et al. (2010): Selecting appropriate bedding to reduce locomotion problems in broilers, Braz J of Poultry Sci, 12, 189-195.

2. An YH, Draughn RA (2000): Mechanical testing of bone and the bone-implant Interface, CRC-Press, Boca Raton, USA.

3. Benyi K, Tshilate TS, Netshipale AJ, Mahlako KT (2015): Effects of genotype and sex on the growth performance and carcass characteristics of broiler chickens, Trop Anim Health Prod, 47, 1225-1231.

4. Bessei W (2006): Welfare of broilers: A review, Worlds Poult Sci J, 62, 455-466.

5. Bogosavljević-Bosković S, Kurćubić V, Petrović M., et al. (2006): The effect of season and rearing systems on meat quality traits, Czech J Anim Sci, 51, 369-374.

6. Castellini C, Mugnai C, Dal Bosco A (2002a): Meat quality of three chicken genotypes reared according to the organic system, Ital J Food Sci, 14, 401-412.

7. Castellini C, Mugnai C, Dal Bosco A (2002b): Effect of organic production system on broiler carcass and meat quality, Meat Sci, 60, 219-225.

8. Cavusoglu E, Petek M, Abdourhamane IM, et al. (2018): Effects of different floor housing systems on the welfare of fast-growing broilers with an extended fattening period, Arch Anim Breed, 61, 9-16.

9. De Almeida EA, De Souza LFA, Sant'Anna AC, et al. (2017): Poultry rearing on perforated plastic floors and the effect on air quality, growth performance, and carcass injuries-Experiment 1: Thermal Comfort, Poult Sci, 96, 3155-3162. 
10. De Jong IC, Gunnink H (2014): Wet litter not only induces footpad dermatitis but also reduces overall welfare, technical performance, and carcass yield in broiler chickens, J Appl Poultry Res, 23, 51-58.

11. De Jong I, Berg C, Butterworth A, et al. (2012): Scientific report updating the EFSA opinions on the welfare of broilers and broiler breeders, EFSA Supporting Publications, 9, 1-116.

12. Emmerson DA (1997): Commercial approaches to genetic selection for growth and feed conversion in domestic poultry, Poult Sci, 76, 1121-1125.

13. Fanatico AC, Pillai PB, Cavitt LC, et al. (2005): Evaluation of slower-growing broiler genotypes grown with and without outdoor access: Growth performance and carcass yield, Poult Sci, 84, 1321-1327.

14. Gardner MJ, Silva MJ, Krieg JC (2012): Biomechanical testing of fracture fixation constructs: Variability, validity, and clinical applicability, J Am Acad Orthop Surg, 20, 8693.

15. Gordon SH, Charles DR (2002): Niche and organic chicken products, Nottingham University Press, Nottingham, UK.

16. Hester PY (1994): The role of environment and management on leg abnormalities in meat-type fowl, Poult Sci, 73, 904-915.

17. Hunton P (1997): Poultry genetics 1950-1997: Some unexpected side effects, In: Proceedings of the Australian Poultry Science Symposium, Sydney.

18. Husak RL, Sebranek JG, Bregendahl K (2008): A survey of commercially available broilers orginating from organic, free-range and conventional production systems for meat yields, composition and relative value, Poult Sci, 87, 23672376.

19. Jepsen KJ, Silva MJ, Vashishth D, et al. (2015): Establishing biomechanical mechanisms in mouse models: Practical guidelines for systematically evaluating phenotypic changes in the diaphyses of long bones, J Bone Miner Res, 30, 951-966.

20. Jones DR, Guard J, Gast RK, et al. (2016): Influence of commercial laying hen housing systems on the incidence and identification of Salmonella and Campylobacter, Poult Sci, 95, 1116-1124.

21. Kestin SC, Su G, Sorensen P (1999): Different commercial broiler crosses have different susceptibilities to leg weakness, Poult Sci, 78, 1085-1090.

22. Kestin SC, Knowles TG, Tinch AE, et al. (1992): Prevalence of leg weakness in broiler chickens and its relationship with genotype, Vet Rec, 131, 190-194.

23. Knowles TG, Broom DM (1990): Limb bone strength and movement in laying hens from different housing systems, Vet Rec, 126, 354-356.

24. Leeson S, Caston L, Summers JD, et al. (2000): Performance of male broilers to $70 d$ when fed diets of varying nutrient density as mash or pellets, J Appl Poult Res, 8, 452-464.

25. Lewis PD, Perry GC, Farmer LJ, et al. (1997): Responses of two genotypes of chicken to the diets and stocking densities typical of UK and "Label Rouge" systems: I. Performance, behaviour and carcass composition, Meat Sci, 45, 501-516.

26. Lilburn MS (1994): Skeletal growth of commercial poultry species, Poult Sci, 73, 897-903.
27. Marin RH, Fretes P, Gusman D, et al. (2001): Effects of an acute stressor on fear and on the social reinstatement responses of domestic chicks to cage mates and strangers, Appl Anim Behav Sci, 71, 57-66.

28. McDevitt RM, McEntee GM, Rance KA (2006): Bone breaking strength and apparent metabolisability of calcium and phosphorus in selected and unselected broiler chicken genotypes, Br Poult Sci, 47, 613-621.

29. Merkley JW, Wabeck CJ (1975): Cage density and frozen storage effect on bone strength of broilers, Poult Sci, 54, 1624-1627.

30. Moyle JR, Arsi K, Woo-Ming A, et al. (2014): Growth performance of fast-growing broilers reared under different types of production systems with outdoor access: Implications for organic and alternative production systems, J Appl Poult Res, 23, 212-220.

31. National Research Council (NRC) (1994): Nutrient Requirements of Poultry, The National Academic Press, Washington.

32. Ono Y, Yamamoto S, Akao T, et al. (2012): Mechanical testing of bone strength after radiofrequency ablation treatment, Journal of JSEM, 12, 261-266.

33. Petek M, Ustuner H, Yesilbag D (2014): Effects of stocking density and litter type on litter quality and growth performance of broiler chicken, Kafkas Univ Vet Fak Derg, 20, 743-748.

34. Petracci M, Mudalal S, Soglia F, et al. (2015): Meat quality in fast-growing broiler chickens, World Poultry Sci J, 71, 363-374.

35. Pierson FW, Hester PY (1982): Factors influencing leg abnormalities in poultry: A review, World Poultry Sci J, 38, 5-17.

36. Ponte PIP, Rosado CMC, Crepso JP, et al. (2008): Pasture intake improves the performance and meat sensory attributes of free-range broilers, Poult Sci, 87, 71-79.

37. Rath NC, Huff GR, Huff WE, et al. (1999): Factors regulating bone maturity and strength in poultry, Poult Sci, 79, 1024-1032.

38. Ravindran V, Thomas DV, Thomas DG, et al. (2006): Performance and welfare of broilers as affected by stocking density and zinc bacitracin supplementation, Anim Sci J, 77, 110-116.

39. Regmi R, Nelson N, Haut RC, et al. (2017): Influence of age and housing systems on properties of tibia and humerus of Lohmann White hens: Bone properties of laying hens in commercial housing systems, Poult Sci, 96, 3755-3762.

40. Reiter K, Bessei W (1995): Influence of running on leg weakness of slow and fast growing broilers, In: Proceedings of the 29th International Congress of the International Society of Applied Ethology, Exeter, UK.

41. Richards M, Poch S, Coon C, et al. (2003): Expression of selected genes related to fat metabolism in broiler breeder chickens, J Nutr, 131, 707-715.

42. Rodenburg TB, Tuyttens FAM, De Reu K, et al. (2008): Welfare assessment of laying hens in furnished cages and non-cage systems: an on-farm comparison, Anim Welf, 17, 363-373.

43. Santos AL, Sakomura NK, Freitas ER, et al. (2005). Comparison of free range broiler chicken strains raised in confined and semi-confined systems, Braz J Poult Sci, 7, 8592. 
44. Silversides FG, Singh R, Cheng KM, et al. (2012): Comparison of bones of 4 strains of laying hens kept in conventional cages and floor pens, Poult Sci, 91, 1-7.

45. Snedecor GW, Cochran WG (1989): Statistical Methods. Iowa State University Press, Ames, IA, USA.

46. Sorensen P (1992): The genetics of leg disorders. In: CC Whitehead (Ed). Bone Biology and Skeletal Disorders in Poultry. Carfax Publishing, London. 213-229.

47. Świątkiewicz S, Arczewska-Wlosek A (2012): Bone quality characteristics and performance in broiler chickens fed diets supplemented with organic acids, Czech J Anim Sci, 57, 193-205.

48. Taha AE, Abd El-Ghany FA, Sharaf MM (2011): Strain and sex effects on productive and slaughter performance of local Egyptian and Canadian chicken strains, J World Poult Res, 1: 11-17.

49. Tolon B, Yalcin S (1997): Bone characteristics and body weight of broilers in different husbandry systems, $\mathrm{Br}$ Poult Sci, 38, 132-135.

50. Tong HB, Wang Q, Lu J, et al. (2014): Effect of free-range days on a local chicken breed: Growth performance, carcass yield, meat quality, and lymphoid organ index, Poult Sci, 93, 1883-1889.

51. Tufekci K, Kayacan R, Kurbanoglu C (2014): Effects of gamma radiation sterilization and strain rate on compressive behavior of equine cortical bone, J Mech Behav Biomed Mater, 34, 231-242.

52. Udeh I, Ezebor PN, Akporahuarbo, PO (2015): Growth performance and carcass yield of three commercial strains of broiler chickens raised in a tropical environment, J Biol Agric Healthc, 2, 62-67.
53. Vercoe JE, Fitzhugh HA, Von Kaufmann R (2000): Livestock productions systems beyond 2000, Asian Australas J Anim Sci 13, 411-419.

54. Vitorovic D, Nikolic Z (1995): Longitudinal growth of leg and wing bones of chickens reared in cages and on the floor, Anat Histol Embryol, 24, 81-83.

55. Wang KH, Shi SR, Dou TC, et al. (2009): Effect of a freerange raising system on growth performance, carcass yield, and meat quality of slow-growing chicken, Poult Sci, 88, 2219-2223.

56. Wolff J (1986): The Law of Bone Remodeling. SpringerVerlag, Berlin, Heidelberg, Germany.

57. Yalcin S, Ozkan, S, Coskuner E, et al. (2001): Effects of strain, maternal age and sex on morphological characteristics and composition of tibial bone in broilers, Br Poult Sci, 42, 184-190.

58. Yildiz H, Petek M, Gunes N, et al. (2003): Effects of different housing systems on various parameters of the humerus and tibiotarsus in chickens (Tetra SL), Turk J Vet Anim Sci, 27, 979-982.

59. Yilmaz BD, Ipek A, Sahan U, et al. (2016): Egg production and welfare of laying hens kept in different housing systems (conventional, enriched cage, and free range), Poult Sci, 95, 1564-1572.

60. Young LL, Northcutt JK, Buhr RJ, et al. (2001): Effects of age, sex, and duration of postmortem aging on percentage yield of parts from broiler chicken carcasses, Poult Sci, 80, 376-379. 